\title{
PENGELOLAAN KEBUN SECARA BERKELANJUTAN PADA MASYARAKAT ARFAK DI KABUPATEN PEGUNUNGAN ARFAK PROPINSI PAPUA BARAT
}

\section{SUSTAINABLE GARDENING MANAGEMENT IN THE ARFAK FARMER TRIBE AT KABUPATEN PEGUNUNGAN ARFAK, PROVINCE OF PAPUA BARAT}

\author{
Alexander Yaku'), Darius Trirbo ${ }^{2)}$, Audry Siahaenenia ${ }^{3)}$, Sartji Taberima $^{1)}$, \\ Deny A. Iyai ${ }^{4)}$, dan Hanike Monim ${ }^{4)}$ \\ ${ }^{1)}$ Fakultas Pertanian, Universitas Papua, ${ }^{2}$ Yayasan Sinar Hugbey Rinya,Manokwari Selatan, Papua Barat, \\ ${ }^{3)}$ Conservation International-Indonesia, Jakarta, ${ }^{4)}$ Fakultas Peternakan, Universitas Papua \\ Email: da.iyai@yahoo.com
}

\begin{abstract}
ABSTRAK
Pegunungan Arfak memiliki kondisi agroekologi penting. Masyarakat Arfak memiliki kearifan dalam bercocok tanam, memiliki hubungan yang dekat dengan kebun. Penelitian dilakukan dengan metode deskriptif melalui observasi dan wawancara dilakukan pada keluarga petani masyarakat Arfak. Hasil kajian menunjukkan bahwa pemanfaatan lahan kebun oleh masyarakat Arfak terbatas pada segi pemanfaatan ruang dan sumberdaya lahan. Kondisi lahan curam $>60 \%$, rawan banjir dan longsor. Lahan dibuka dengan sistem tebang dan bakar. Kandungan bahan organik umumnya sangat tinggi pada lapisan permukaan, dan menurun sedikit pada lapisan di bawahnya. Masyarakat Arfak sudah mempraktekkan sistem agroforestri kompleks maupun sederhana. Terdapat lima pola aliran energi dalam sistem kebun yang belum dimanfaatkan secara efektif dan efisien. Ditemukan juga lima situasi/kondisi prospek dan konstrain dalam keberlanjutan pertanian di Pegunungan Arfak. Kebun, ternak babi dan serta masyarakat Arfak saling berinteraksi dengan memberikan servis dari dan untuk masing-masing komponen. Kebun mampu membantu petani masyarakat Arfak secara ekonomis, ekologis dan sosiologis.
\end{abstract}

Kata kunci: agroforestri; babi; kebun; Pegunungan Arfak; masyarakat Arfak

\begin{abstract}
The Arfak Mountains have important agroecological conditions. Arfak community have local wisdom in farming, have a close relationship with the garden. Research was conducted with descriptive methods through observations and interviews conducted on Arfak farming families. The results of the study indicate that the use of garden land by Arfak people is limited in terms of land use and land resources. Steep land conditions is $>60 \%$, prone to flooding and landslides. The land is opened by cutting and burning systems. The content of organic matter is generally very high in the surface layer, and decreases slightly in the layers below. The Arfak community has also used the practices of complex and simple agroforestry. There are five energy flow patterns in the garden system that have not been used effectively and efficiently. Also found are five situations/conditions prospects and constraints in agricultural sustainability in the Arfak Mountains. Farms, pigs and Arfak community interact each other by providing services from and for each component. The gardens are able to help Arfak farmers economically, ecologically and sociologically.
\end{abstract}

Keywords: agroforestry; Arfak community; Arfak Mountains; garden;pig 


\section{PENDAHULUAN}

Masyarakat Indonesia adalah masyarakat agraris tropis (Hafsah, 2009) karena lebih dari $80 \%$ penduduknya menggantungkan matapencahariannya pada lahan kebun, baik kebun pada pekarangan maupun pada lahan hak ulayat yang dikuasai keluarga dan lahan milik perusahaan perkebunan. Hal ini ditandai juga dengan status swasembada pertanian secara khusus pada komoditas beras di era 1980an. Namun prestasi ini sulit dipertahankan. Hal ini disebabkan karena lahan-lahan kebun vital dikonversi untuk peruntukan lain seperti mall, real estate dan insfrastruktur lainnya. Tidak hanya di bagian Barat Indonesia, hal ini juga terjadi pada bagian Timur Indoensia. Salah satunya di Pegunungan Arfak yang merupakan daerah otonom baru di Papua Barat, Indonesia.

Rata-rata halaman rumah keluarga masyarakat Arfak dikelilingi lahan kebun. Kebun merupakan sebidang lahan, biasanya di tempat terbuka, yang mendapat perlakuan tertentu oleh manusia, khususnya sebagai tempat tumbuh tanaman. Kebun adalah sistem produksi yang menyuplai tanaman dan pakan ternak dan hal yang dapat termanfaatkan (Ninez, 1987). Sejauh ini lahan halaman rumah petani belum dikelola dengan baik untuk memaksimalkan produksi dan produktifitas lahan serta produk tanaman yang ditanam (Suhardi et al., 2002). Penataan letak dan luas lahan yang diperuntukan bagi keperluan tanaman lainnya belum dibangun dengan baik. Misalnya, lahan yang disediakan untuk tanaman obat, lahan untuk sayur mayur, lahan untuk buah-buahan pekarangan, lahan untuk tanaman rempah-rempah dan lahan untuk tanaman hias. Hal ini penting karena visi dan misi kabupaten Pegunungan Arfak saat ini adalah menjadikan Kabupaten Pegunungan Arfak sebagai kabupaten Agrowisata pegunungan tinggi.

Unit terkecil dari sebuah sistem pertanian yang kompleks adalah petani (Bunch 1991; Chambers et al., 1989). Selama ini petani/peternak di Indonesia telah diabaikan peranannya dalam pembangunan (Hasibuan, 2012). Pemerintah lebih memilih import produk pangan (Suratiyah, 2008). ketimbang membangun kemandirian pangan bangsa melalui program strategis dan pembenahan internal. Tidak heran apabila sektor pertanian menjadi sektor yang penuh dengan mafia perdagangan import hasil pertanian/ternak dan daging (Himawan, 2017; Herudin, 2017). Untuk itu, mengharapkan swasembada hasil pertanian/daging (Hafsah, 2009) dari sektor ini relatif sulit dicapai. 
Selama ini percepatan pembangunan pertanian di Indonesia telah berjalan cukup baik namun kurang menjanjikan karena pada tatanan hulu pertanian skala rumah tangga (Soekartawi, 2005) belum dibina dan ditata dengan baik. Artinya bahwa, pada tatanan/aras petani saja masih terdapat banyak hal yang harus dibenahi sehingga dapat memberikan kepastian dalam berusaha atau melakukan aktifitasaktifitas agribisnis (Soekartawi, 2010). Secara detail pertanian skala rumah tangga belum dipersiapkan dan dikelola dengan memanfaatkan sejumlah asset sumberdaya (on-farm) yang dimiliki. Misalnya sumberdaya lahan (Salim, 1988) (Iskandar, 1992), pakan ternak (Sukria and Krisnan, 2009), limbah (Guntoro, 2008) dan lain sebagainya. Oleh karena itu tujuan penelitian ini adalah memotret kondisi eksisting fisik dan non fisik sistem lahan pertanian dan kebun keluarga masyarakat Arfak yang sedang dikerjakan di Pegunungan Arfak, Papua Barat, Indonesia.

\section{METODE PENELITIAN}

\section{Waktu, lokasi dan subyek}

Penelitian lapangan dilakukan selama 2 bulan yaitu bulan SeptemberNopember 2018. Letak Geografis Kabupaten Pegunungan Arfak adalah pada Bagian Utara: $0^{\circ} 55^{\prime}$ Lintang Selatan; Bagian Selatan: $1^{\circ} 40^{\prime}$ Lintang Selatan;
Bagian Barat: $133^{\circ} 10^{\prime}$ Bujur Timur; Bagian Timur : $134^{\circ} 05^{\prime}$ Bujur Timur. Penentuan lokasi dilakukan secara sampling terhadap 2 distrik dari 10 distrik di wilayah Pemerintahan Kabupaten Pegunungan Arfak yang dijadikan sebagai sasaran penelitian.

\section{Subyek dan Obyek serta variabel penelitian}

Subyek penelitian ini adalah petani yang memiliki kebun pekarangan. Obyek penelitian ini terdiri atas berbagai aspek yang berhubungan dengan lingkungan geografis, fisiografis, kawasan bencana, sumberdaya lahan pertanian, dan pemanfaatan pekarangan. Metode yang digunakan dalam penelitian adalah deskriptif dengan teknik survei (Yin, 2000). Selanjutnya, diambil sampel tanah sesuai lokasi penelitian untuk dianalisis di Laboratorium Tanah UNIPA di Manokwari. Data mengenai luas tanah, penyebaran jenis tanah, dan pola peruntukan sumberdaya tanah hutan serta profil kebun keluarga masyarakat Arfak dikaji dengan bantuan Sistem Informasi Geografis (SIG) yang ditunjang dengan kegiatan survei dan pengamatan.

\section{Pengumpulan dan analisis data}

Pengumpulan data dilakukan dengan metode wawancara dan pengamatan langsung terhadap subyek dan obyek 
penelitian. Wawancara dilakukan dengan cara mengisi data/informasi ke dalam daftar pertanyaan yang telah disiapkan sebelumnya. Demikian pula dilakukan pengamatan terhadap obyek dan subyek penelitian untuk meyakinkan dan/atau menyesuaikan antara data/informasi dengan kenyataan yang sebenarnya. Sumber data diperoleh dari hasil interview dan studi pustaka (Moleong, 1991). Secara teknis, tim peneliti bersama petani mengunjungi lahan usahatani yang sedang dikelola, maupun lahan yang telah dan akan dikelola. Gambar profil lahan dan pola pemanfaatan lahan dibuat dengan menggunakan Microsoft Visio. Data/informasi dianalisa dan diinterpresi secara deskriptif naratif.

\section{Hasil dan Pembahasan}

\section{Topografi Ekologi Pegunungan Arfak Aspek geografis}

Secara fisik geografis luas wilayah kabupaten Pegunungan Arfak adalah $2.773,74 \mathrm{~km}^{2}$, membawahi 10 distrik dan 166 kampung. Batas wilayah Kabupaten Pegunungan Arfak meliputi Sebelah Utara berbatasan dengan distrik Warmare, distrik Tanah Rubuh, dan distrik Prafi kabupaten Manokwari. Sebelah Timur berbatasan dengan distrik Oransbari, distrik Ransiki, dan distrik Neney kabupaten Manokwari Selatan. Sebelah Selatan berbatasan langsung dengan distrik Moskona Utara dan distrik Manimeri Kabupaten Teluk Bintuni, dan distrik Dataran Isim kabupaten Manokwari Selatan. Sebelah Barat berbatasan dengan distrik Sidey kabupaten Manokwari, dan distrik Kebar Kabupaten Tambrauw. Ketinggian wilayah Kabupaten Pegunungan Arfak adalah 300 - 1.800 meter dpl. Dari segi luas wilayah menurut distrik, Testega merupakan distrik dengan wilayah paling luas (75.515 ha atau $19,65 \%$ dari luas wilayah Kabupaten Pegaf), diikuti distrik Catubouw (72.237 ha atau $18,80 \%$ dari luas wilayah Kabupaten Pegaf); sedangkan distrik dengan luas wilayah paling sempit adalah Membey (10.370 ha atau 2,37\% dari luas wilayah Kabupaten Pegaf), diikuti distrik Anggi (14.114 ha atau 3,67\% dari luas wilayah Kabupaten Pegaf).

\section{Aspek Fisiografi}

Dari segi fisiografi, distrik dengan persentasi wilayah paling banyak masuk dalam kategori extremly steep (sangat curam dengan kemiringan $>40 \%$ ) adalah Minyambouw (73,83\%), diikuti oleh Membey (66,32\%); sedangkan distrik dengan flat (kategori berbukit dengan kemiringan $<2 \%$ ) dan very gentle (bergelombang dengan kemiringan 2 - 8\%) adalah Anggi (17,61\%), diikuti oleh Taige $(8,91 \%)$. Data Profil Kabupaten Pegaf Tahun 2013 menyatakan bahwa hanya 
$20 \%$ wilayahnya memiliki kemiringan 0 $25^{\circ}$ (datar), selebihnya $80 \%$ wilayahnya memiliki kemiringan lebih dari $25^{\circ}$ (bergelombang/berbukit).

Peta administrasi Kabupaten Pegunungan Arfak ditampilkan pada Gambar 1.

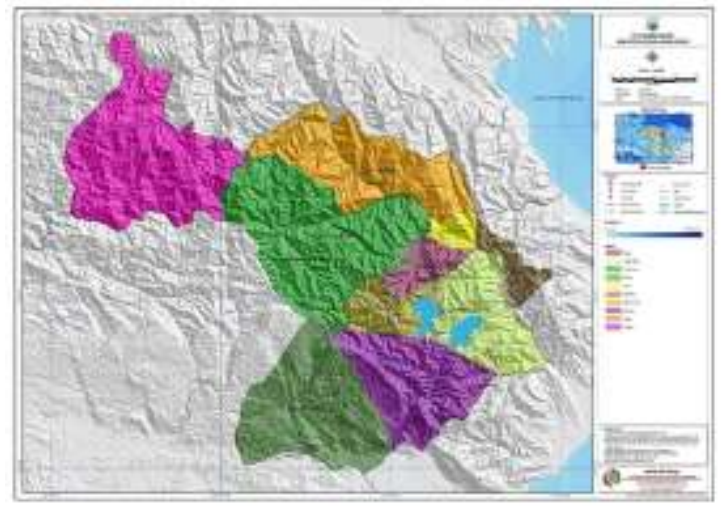

Gambar 1. Peta administrasi Kabupaten Pegunungan Arfak. Sumber: Wikipedia Indonesia

\section{Kawasan Bencana}

Kawasan rawan bencana longsor terdapat di hampir semua distrik dan kampung di wilayah Kabupaten Pegunungan Arfak. Hal ini karena distrik dan kampung di wilayah kabupaten ini terletak di lembah kecil (uvale) yang dikelilingi/dipagari oleh pegunungan yang menjulang tinggi. Demikian pula, banyak kampung yang terletak di punggung gunung yang curam sampai sangat curam (very steep/kemiringan $41-60 \%$ sampai extreemly steep/tingkat kemiringan $>60 \%$ ) sangat rawan terhadap longsor dan banjir. Sebagian besar kawasan distrik Minyambouw, Catoubouw, Hingk, Sururey, Anggi, Anggi Gida, Taige,
Testega, Didohu, dan Membey karena berada pada lingkungan alam fisik yang very steep sampai extreemly steep sangat rawan terhadap banjir dan longsor.

Gerakan tanah/longsor di wilayah ini merupakan jenis bencana alam yang paling sering terjadi. Hampir setiap tahun atau musim hujan menimbulkan bencana kerusakan dan korban jiwa, walaupun dimensi bencana gerakan tanah relatif kecil jika dibandingkan dengan bencana gempa bumi atau letusan gurung api. Jenis gerakan tanah yang sering terjadi adalah longsoran tanah dan material dengan tingkat waktu kerjadian antara sangat lambat hingga cepat. Hal ini dipengaruhi oleh curah hujan (air) yang menjenuhi tanah penutup yang sangat tebal.

Persoalan yang terjadi adalah selama ini program pemberdayaan petani/peternak tidak terintegrasi. Hal ini menyebabkan friksi tersendiri pada kalangan petani/peternak. Setiap dinas baik itu dinas peternakan, pertanian dan perkebunan, perikanan dan kehutanan masing-masing memiliki program pada beberapa kampung/desa binaan. Kelompok pun tak terhindarkan dibentuk. Hal ini menyebabkan peternak/petani menjadi bingung mengeksekusinya program kerja dalam kampung. 


\section{Lahan Pertanian Dataran Tinggi}

\section{Lahan Pertanian}

Lahan pertanian yang tersedia di Pegunungan Arfak adalah sebesar Dari segi fisiografi, distrik dengan persentasi wilayah paling banyak masuk dalam kategori extremly steep (sangat curam dengan kemiringan $>40 \%$ ) adalah Minyambouw (73,83\%), diikuti oleh Membey (66,32\%); sedangkan distrik dengan flat (kategori berbukit dengan kemiringan $<2 \%$ ) dan very gentle (bergelombang dengan kemiringan 2 - 8\%) adalah Anggi (17,61\%), diikuti oleh Taige (8,91\%). Data Profil Kabupaten Pegaf Tahun 2013 menyatakan bahwa hanya $20 \%$ wilayahnya memiliki kemiringan 0$25^{\circ}$ (datar), selebihnya $80 \%$ wilayahnya memiliki kemiringan lebih dari $25^{\circ}$ (bergelombang/berbukit).

Ubi jalar masih merupakan tanaman pangan utama walau introduksi beras "Raskin" secara perlahan mulai menggeser peran ubi-ubian sebagai sumber pangan (Mulyadi, 2012). Namun beras bukan merupakan komoditas lokal yang dapat dengan mudah dibudidayakan sesuai dengan agroekologi dan budaya masyarakat lokal (Arifin et al., 2009; Mahendra, 2009). Tanaman padi sangat sensitif terhadap perubahan agroklimat (Mahendra, 2009) dan budidayanya membutuhkan penanganan intensif dengan input produksi tinggi. Sedangkan ubi jalar dan jenis tanaman pangan lokal ubi-ubian lainnya dapat memberikan hasil tanpa pembudidayaan yang intensif dan hanya dengan menggunakan input produksi yang rendah. Oleh sebab itu, ketersediaan ubi jalar dan tanaman pangan lokal lainnya sangat penting untuk menunjang ketahanan pangan di wilayah Pegunungan Arfak. Namun demikian, hal-hal yang perlu ditingkatkan dalam budidaya ubi jalar adalah penggunaan stek yang berkualitas dan pembuatan gundukan tanah (kuming atau bedeng) untuk meningkakan hasil umbi.

\section{Siklus pembukaan lahan}

Siklus pembukaan lahan kebun di wilayah Pegunungan Arfak dimulai ketika tanaman ubi jalar ditanam bersama dengan tanaman sayuran dan pangan lainnya dan berakhir setelah ubi jalar dipanen dalam kurun waktu 1 tahun sejak penanaman. Sedangkan tanaman sayuran berupa labu kuning (Cucurbita moschata), buncis (Phaseolus vulgaris) dan jagung (Zea mays) dipanen setelah berumur 3 bulan. Setelah 3 bulan pada lahan kebun hanya dijumpai ubi jalar dan beberapa tanaman lainya yang dibiarkan merambat menempati seluruh permukaan tanah. Panen ubi jalar pertama dilakukan pada umur 8 - 9 bulan. Panen ubi jalar dilakukan secara bertahap selama kurang 
lebih 3 - 4 bulan. Sebelum panen, stek ubi jalar telah disiapkan untuk ditanam di kebun baru. Cara panen bertahap ini dilakukan karena tidak tersedianya tempat penyimpanan yang dapat memperpanjang umur simpan ubi jalar.

\section{Sistem tebang bakar}

Dalam sistem tebang bakar, kegiatan pembukaan hutan biasanya dimulai pada awal musim kering. Pada tahap pemotongan, ranting dan sulur, gulma, semak dibabat hingga rata dengan tanah. Kemudian pohon-pohon besar ditebang hingga lahan terbuka dan terbebas dari naungan. Abu hasil pembakaran dibiarkan pada lahan, karena petani percaya bahwa abu tersebut dapat menyuburkan lahan. Penebangan pohon masih menggunakan alat sederhana, yaitu kapak dan parang, namun ada pula petani yang menggunakan chainsaw. Dalam proses penebangan tidak semua pohon ditebang habis, hanya dipangkas ranting-ranting dan pada bagian bawah batang pohon dikuliti untuk memutus proses penyerapan makanan sehingga pohon tersebut kering dan mati. Dapat dilihat bahwa pada kebun masyarakat selalu nampak pohon kayu yang dibiarkan kering. Pohon akan ditebang ketika dibutuhkan sebagai kayu bakar di rumah.

$$
\text { Kegiatan pembukaan lahan }
$$
dilakukan secara gotong royong oleh anggota keluarga. Karena kebun umumnya milik anggota keluarga, maka tenaga kerja yang terlibat merupakan anggota keluarga, sedangkan pekarangan rumah milik pribadi setiap keluarga masing-masing. Tenaga kerja yang terlibat dalam mengelola pekarangan merupakan tenaga kerja pribadi dari masing-masing rumah tangga. Untuk kebun, pertama-tama rumput atau semak dibabat, kemudian pohon besar dibakar, dimana memerlukan waktu sekitar 5 hari untuk kebun besar atau 2-3 hari untuk kebun kecil. Pada beberapa wilayah di Pegunungan Arfak, tenaga kerja perempuan juga melakukan kegiatan persiapan lahan untuk kebun (Gambar 2). Pengolahan tanah di areal kebun dilakukan secara minimum, di mana saat selesai pembakaran dan pembersihan, masyarakat pada umumnya langsung menanam bibit atau benih dengan cara membuat lubang tanam dengan menggunakan tugal. Tugal terbuat dari kayu pohon lokal, disebut kingi, minyei dan brab. Lahan kebun masyarakat Arfak secara umum dan intensif dikelola dengan menggunakan metode conservation tillage (CT) (Peigné et al., 2018; Syed, 2018). Selama waktu menunggu panen masyarakat melakukan perburuan babi hutan, kuskus, tikus tanah dan burung yang merupakan pelengkap gizi. Selain berburu beberapa masyarakat adat melakukan penangkapan ikan di danau. 
Pada akhir panen, lahan akan dijadikan tempat penggembalaan babi. Dengan demikian ternak babi secara tidak langsung berperan pula dalam pengolahan tanah.

\section{Teknik bercocok tanam}

Teknik bercocok tanam dilakukan secara campuran (Arifin et al., 2009), yaitu satu lahan ditanami dengan beragam tanaman sayuran, antara lain daun bawang, wortel, labu siam, kol, petsai, buncis, labu kuning, kacang tanah, kentang, jagung. Ubi jalar mendominasi areal penanaman di pekarangan maupun kebun (Mulyadi, 2012). Selain ubi jalar, tanaman pangan lain yang dibudidayakan adalah talas namun dalam skala kecil, karena tanaman ini sebenarnya merupakan tanaman yang baru diintroduksi dari dataran rendah. Tanaman buah terutama nenas ditanam di lereng bukit, sedangkan markisa tumbuh liar dan merambat pada pohon-pohon di tepi hutan.

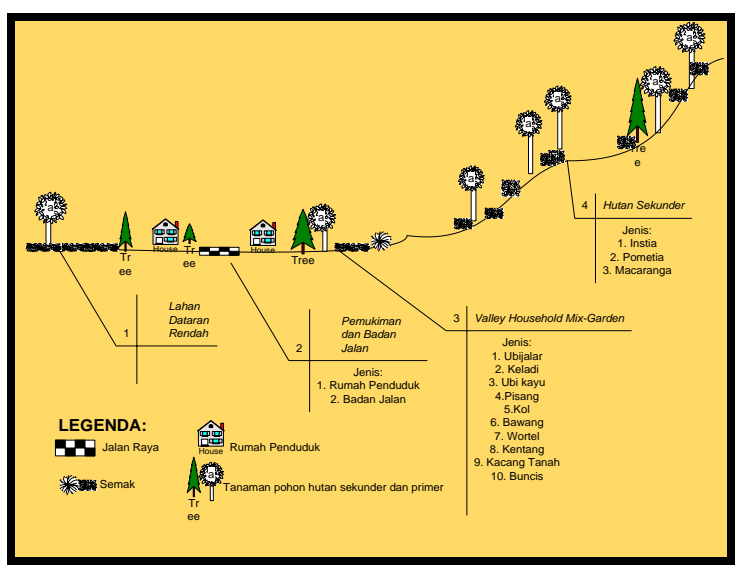

Gambar 2. Profil Transek Kebun Keluarga Dataran Tinggi Pegunungan Arfak
Beberapa jenis tanaman seperti kubis, sawi, bawang daun dan wortel ditanam secara monokultur yang dikelilingi oleh berbagai tanaman lainnya dalam sistem campuran. Sistem budidaya seperti ini dan menetap pada umumnya terdapat di lahan pekarangan rumah, namun beberapa petani di distrik Taige membuat sistem monokultur kol, sawi dan wortel di lahan kebun yang letaknya di luar rumah, tepatnya di tepi jalan raya, dengan tujuan untuk memudahkan pengangkutan dengan kendaraan ke pasar saat panen. Sistem pertanian yang dipraktekkan secara turun temurun berupa ladang berpindah dengan cara tebas hutan dan bakar (slash and burn) (Gambar 2 dan 3). Ladang berpindah adalah salah satu kegiatan pokok masyarakat Pegunungan Arfak yang ditujukan untuk alam kembali menyediakan bahan organik sebagai pupuk alam. Praktek berkebun masyarakat Arfak belum sampai pada taraf pengolahan tanah. Teknik atau metode Zero tillage (Salem et al., 2015) atau no tillage (Alberto et al., 2010; Pareja-sánchez et al., 2017) masih dipraktekkan petani etnis Arfak. Petani akan berpindah dari kebun pertama ke kebun berikutnya hingga 3 atau 4 kebun atau lebih, setelah hasil atau produksi kebun pertama menurun. Penurunan hasil terjadi setelah 2 - 3 kali penanaman tanaman sayuran atau 1 kali tanaman ubi jalar dalam 1 tahun. Lama 
pemberaan lahan kurang lebih 3 - 4 tahun, sehingga petani akan kembali ke kebun pertama setelah berotasi selama $3-4$ tahun atau lebih.

\section{Rotasi kebun}

Petani melihat petunjuk bahwa lahan sudah dapat untuk ditanami dari pertumbuhan rumput-rumputan, cabang pohon yang lebat dan pohon-pohon telah mencapai ketinggian tertentu atau jika tanaman pohon sudah ber diameter 4-6 cm. Jenis pohon yang digunakan sebagai indikator tergantung dari wilayah masingmasing. Di wilayah pegunungan Arfak, jenis pohon tersebut memiliki nama lokal Damur (bahasa Hatam).

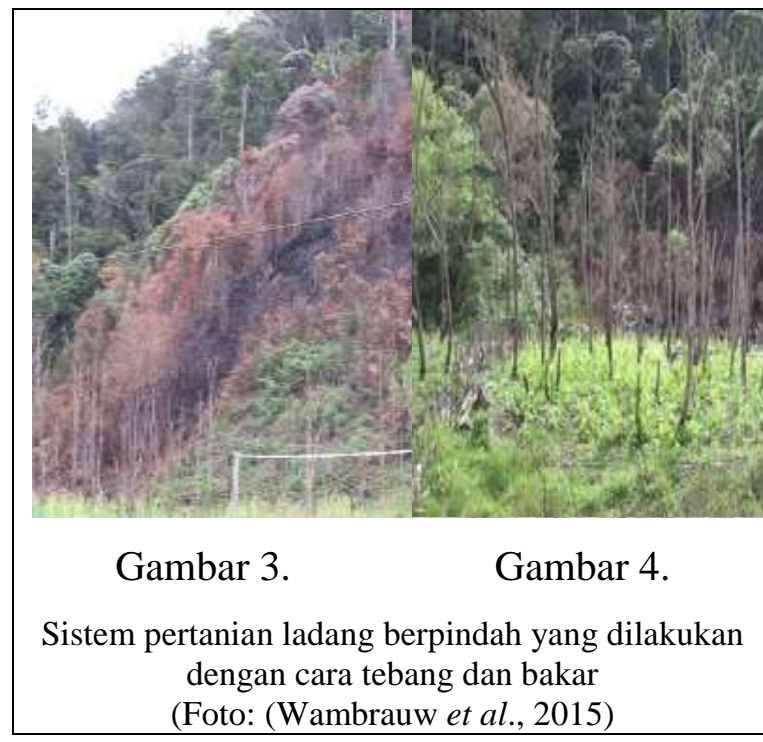

Pada umumnya petani memiliki 2- 4 kebun dengan luas lahan sekitar 2 ha/kebun tetapi tergantung pada jumlah anggota keluarga yang harus ditanggung dalam 1 kebun keluarga. Kesuburan tanah dan jumlah tenaga kerja keluarga. Siklus dan tatacara pembukaan kebun oleh masyarakat Baduy juga dilaporkan oleh (Iskandar, 1992). Luas pekarangan di sekeliling rumah sekitar $0.5-1.0$ ha.

Tidak semua masyarakat di Pegunungan Arfak memiliki kebun di pekarangannya, sebagai contoh di distrik Catubouw sebagian besar masyarakat tidak memanfaatkan pekarangan rumahnya untuk bercocok tanam karena rata-rata luasan pekarangannya lebih kecil, sehingga hampir keseluruhan kegiatan pertanian dilakukan di kebun.

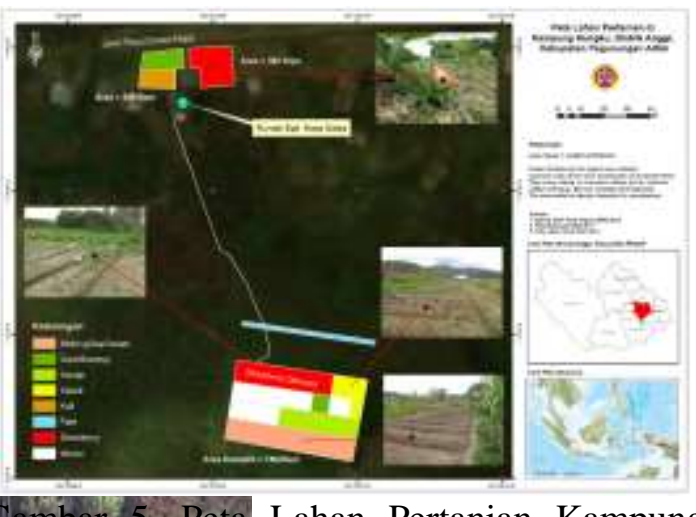

Gambar 5. Peta Lahan Pertanian Kampung N Wungku, Distrik Anggi - Kab. co Pegunungan Arfak (Peta dan Foto: Audry Siahaenenia) Berdasarkan peta lapang di Kampung Hungku pada Gambar 3, terdapat beberapa jenis tanaman sayuran daun dan umbi, serta buah yang berpotensi dibudidayakan dan dikembangkan di lahan pertanian binaan UNIPA, kampung Hungku-Distrik Anggi, contohnya daun bawang, selada keriting, kol bunga, wortel, kentang, kacang kapri, kacang tanah, jagung, buncis, dan brokoli. Sementara 
tanaman buah meliputi stroberi, terong belanda, markisa, dan jeruk sunkis. Kopi arabika (Hulupi et al., 2018;) juga memiliki peluang untuk dapat dikembangkan di dataran tinggi Anggi.

Demikian pula pada Gambar 4, berdasarkan peta lapang di Kecamatan Taige, memiliki status kesuburan tanah yang tidak berbeda jauh dari lahan di Kampung Hungku, sehingga dapat dikembangkan tanaman berikut: daun bawang, seledri, selada keriting, kol bunga, wortel, kentang, kacang tanah, kacang kapri, jagung, buncis, dan brokoli. Tanaman buah meliputi stroberi, terong belanda, markisa, dan jeruk sunkis. Kopi arabika juga memiliki peluang untuk dapat dikembangkan di dataran tinggi Taige.

\section{Manajemen Pemanfaatan Lahan Pekarangan}

\section{Kondisi Eksisting Sistem kebun Keluarga}

Dalam luasan lahan sebesar kurang lebih 1 hektar hanya dapat dimanfaatkan sebesar $<50 \%$ luasan lahan yang tersedia. Masih terdapat sisa luasan lahan yang belum dimanfaatkan secara efektif dan efisien. Hal ini berdampak pada rendahnya produksi dan produktivitas sistem pertanian di daerah Pegunungan Arfak. Dalam sistem ini tanaman dan ternak yang dipelihara adalah kentang, kol, wortel, daun bawang dan jagung. Tanaman lainnya ditanam pada luasan lahan kebun yang relatif berjarak dari rumah penduduk. Tanaman yang biasa ditanam adalah pisang, jagung, labu siam, buah tali.

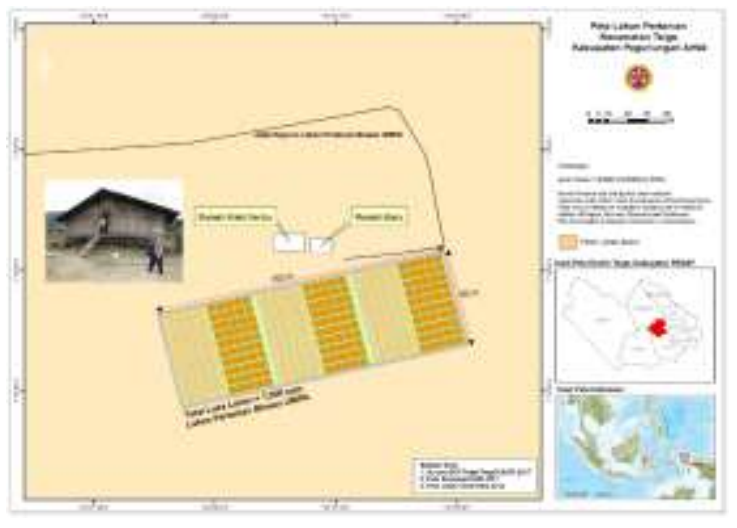

Gambar 6. Peta Lahan Pertanian Kecamatan Taige, Kab. Pegunungan Arfak (Peta dan Foto: Audry Siahaenenia)

Dari Gambar 8. diketahui bahwa terdapat sejumlah lahan-lahan tidur (kode F, tanda: xxx) yang belum dimanfaatkan maksimal. Beberapa luasan lahan hanya ditumbuhi Setaria spp. dan Imperata cylindrica. Penataan kebun dalam upaya menjaga keseimbangan nutrisi tanaman (soil organic matter) dan tanah belum sepenuhnya dikerjakan dengan baik. Pola tanam yang masih tidak teratur menyebabkan hilangnya kesempatan tanaman untuk memperoleh unsur hara. Belum dikembangkannya interaksi pemanfaatan produksi crop residues/wastes tanaman pertanian lainnya sebagai kompos alami (pupuk organic) untuk memperbaiki soil organic matter (SOM) dan mikroorganisme tanah (Hendrik et al., 2016; Pareja-sánchez et al., 2017). Secara garis besar sistem kebun 
rumah tangga yang sedang berlangsung di Pegunungan Arfak dapat gambarkan pada gambar berikut.

Terdapat 5 pola aliran nutrisi pada lahan kebun rumah tangga masyarakat Arfak di Pegunungan Arfak, yaitu $\mathrm{C} \rightarrow \mathrm{B} \rightarrow \mathrm{A}, \quad \mathrm{C} \rightarrow \mathrm{B} \rightarrow \mathrm{F}, \quad \mathrm{C} \rightarrow \mathrm{D} \rightarrow \mathrm{A}$, $\mathrm{C} \rightarrow \mathrm{E} \rightarrow \mathrm{A}$ dan $\mathrm{C} \rightarrow \mathrm{A} \rightarrow \mathrm{F}$. Aliran nutrisi yang terjadi dan dipraktekkan oleh petani masyarakat Arfak adalah sisa produksi sayur mayur dari kebun pekarangan digunakan sebagai pupuk organik lahan ubi dan sisa produksi ubi diberikan kepada ternak babi (CBA). Selain itu, sisa produksi dari lahan ubi diberikan pada lahan di sekitarnya (CBF). Sisa produk lahan sayur-mayur diberikan kepada lahan tanaman rempah dan ternak babi (CDA).
Lahan sayur dimanfaatkan limbahnya untuk tanaman buah dataran tinggi serta hasil dari buah diberikan juga kepada ternak babi. Crops residues diberikan kepada ternak babi dan sisa limbah pakan ternak babi dijadikan sebagai pupuk organik pada lahan pekarangan lainnya (F) untuk kesuburan tanah di sekitar pekarangan (CAF).

Pada tahap ini, masyarakat Arfak telah menggunakan pola agroforestry complex yaitu dengan menggunakan pekarangan (home garden), kebun campuran (mixed garden) dan kebun tahunan (forest garden) (Arifin et al., 2009). Sistem agroforestri sederhana (Arifin et al., 2009) yang diterapkan oleh petani masyarakat Arfak juga telah

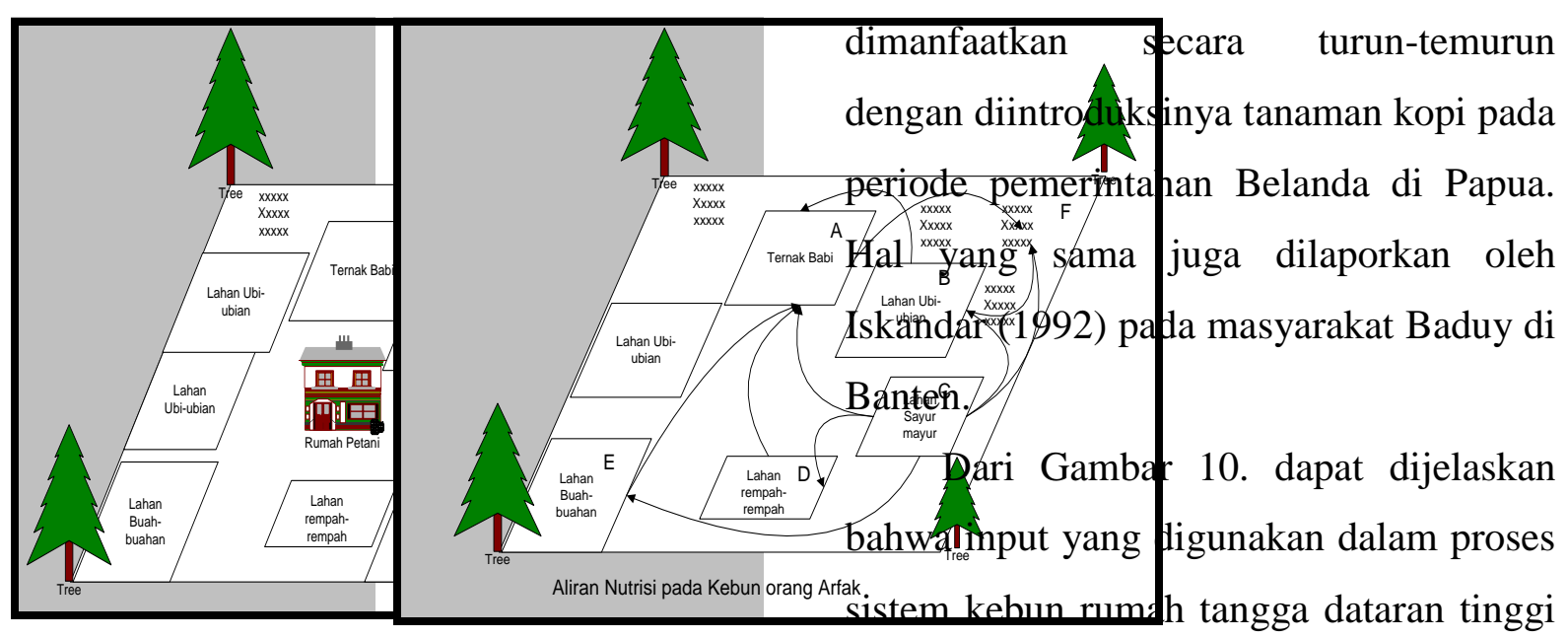

$\begin{array}{cl}\text { Gambar 7. Profil lahan } & \text { Gambar } \\ \text { pekarangan } & \text { Siklus nutrisi } \\ \text { masyarakat } & \text { kebun Mastem } \\ \text { Arfak di } & \text { rakat Arfak. } \\ \text { Pegunungan } & \\ \text { Arfak. } & \end{array}$
adalah air, bibit ternak, bahan bakar, dan bibit tanaman. Bibit ternak dan bibit tanaman sudah diproduksi tetapi dalam jumlah kecil dan terbatas. Hal ini terlihat jelas dalam Gambar 9. Bibit diperoleh dari pasar terdekat seperti di toko pertanian di Manokwari, Prafi dan Ransiki (Manokwari 
Selatan). Air digunakan untuk keperluan lahan, kebun dan rumah tangga. Dalam proses kebun rumah tangga (RT), tenaga kerja RT bekerja di kebun keluarga di sekitar pekarangan rumah dan kebun milik keluarga yang relatif berjarak dari rumah. Bapak dan Ibu, anak-anak dan keluarga famili dekat biasanya turut dalam kegiatan bertani. Hal ini menunjukkan bahwa aktivitas manusia (Anthropogenic activities) dalam hal ini masyarakat Arfak dapat menentukan keragaan tanah (soil property) (Syed, 2018). Gambar berikut adalah konstruksi profil lahan kebun milik masyarakat Arfak.
Ternak kadang dibawa dan diumbar dekat lahan kebun yang akan dibuka dan atau pada lahan umbaran. Pada lahan kebun (sebagai residues) dan lahan umbaran ini ternak memperoleh pakan. Hutan menjadi alternatif petani yang dapat dimanfaatkan untuk memungut beberapa produk hutan dan berburu.

\begin{tabular}{|c|c|c|}
\hline \multirow{2}{*}{ No. } & \multicolumn{2}{|c|}{ Sistem kebun rumah tangga di Anggi } \\
\hline & Prospek & Konstrain \\
\hline 1. & $\begin{array}{l}\text { Masih } \\
\text { menggunakan Low } \\
\text { External Input } \\
\text { berbasis } \\
\text { sumberdaya local }\end{array}$ & $\begin{array}{l}\text { 1. LEI yang } \\
\text { digunakan } \\
\text { masih terbatas } \\
\text { dan belum } \\
\text { dikelola } \\
\text { dengan baik }\end{array}$ \\
\hline
\end{tabular}

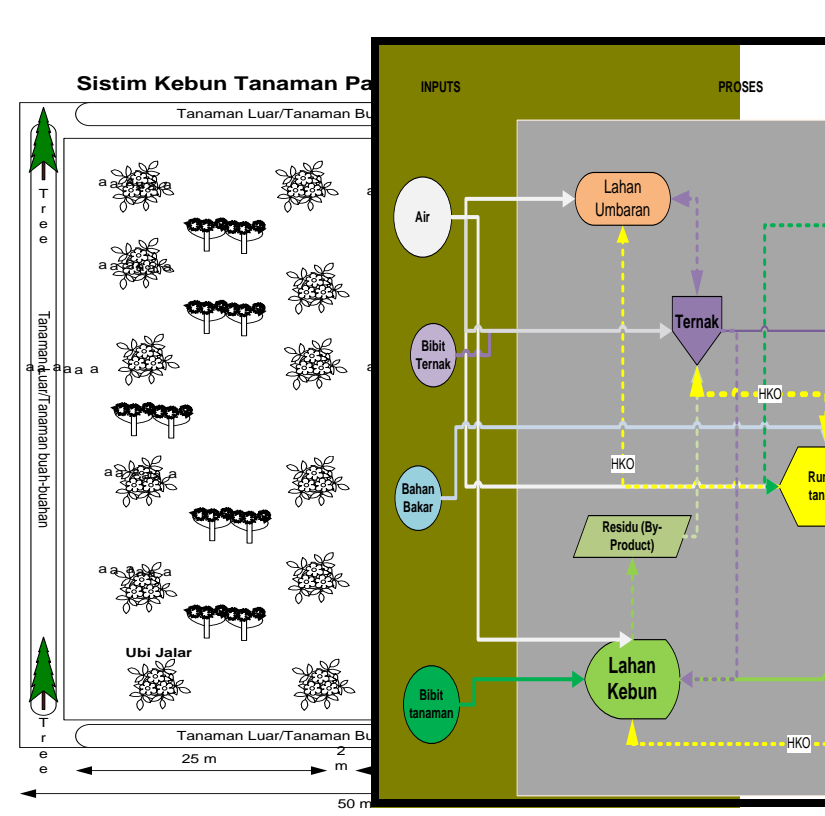

Gambar 9. Profil lahan Gambar 10. Mental Mokebun del Sistem milik ma- Kebun di Dasyarakat taran Tinggi Arfak.
2. Produk hasil pertanian adalah organik

2. Produksi terbatas

3. Lahan tidak luas

4. Jumlah jenis tanaman terbatas

5. Efisiensi produksi rendah dapat diräwat

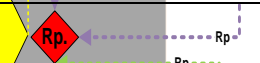

Kelemạha sistem ini perlu diinisiasi dengan memaksimalkan pemanfaatan lahan kebun teluarga sehingga dapat dimanfaatkan sfcara efektif dan efisien. Kegiatan yang dapat dilakukan adalah menata lahan pekarangan sebagaimana model yang telah dijelaskan. Pada model ini tanaman pertanian hortikultur dan buah juga ditanam. Halaman kebun juga ditanami dengan introduksi tanaman hijauan pakan ternak (HPT) ( Suratiyah,
5. Prodúleded àn man Pegunungan Arfak 
2008; Mahendra, 2009). Selain itu ternak sapi/kambing, babi dan ayam dapat dipelihara untuk diambil daging, limbah (slurry) dan telurnya. Kandang diperbaiki dengan bahan lokal untuk sustainabilitas. Tanaman pertanian dan perkebunan ditanam untuk kebutuhan konsumsi keluarga dan perbaikan kesuburan fisik dan kimia tanah. Tanaman rumput dan legum ditanam sebagai pakan ternak (Suhardi et al., 2002). Jika terdapat sumber air, maka kolam ikan dibuat untuk membantu meningkatkan konsumsi protein hewani dan pendapatan petani/peternak. Apabila dimungkinkan, desain biodigester dari bahan sederhana untuk memasak pakan ternak dan air minum masak dapat diberikan ke ternak (Gambar 10).

Memfungsikan kembali (revitalisasi) aliran energi melalui sisa tanaman pertanian dan perkebunan (crop residues) pada ternak dan animal wastes yang dibutuhkan oleh tanaman dapat dilakukan oleh petani masyarakat Arfak. Biofertilizer dibutuhkan sebagai sumberdaya bagi kesuburan tanah dan tanaman pada lahan kebun masyarakat Arfak. Produk tanaman dan sisa panenan dari kebun dapat diberikan kepada ternak. Menggunakan produksi tanaman yang dapat dipanen dan dijual, dihitung produksinya (kg atau ikat/tanaman) serta harga (Rp/ikatan) dan dihitung jumlah residues yang dihasilkan untuk ternak (kg/panen/tanaman). Apabila semua sumberdaya ini telah berjalan dengan lancar, maka perawatan dilakukan sampai dengan penanenan dan penjualan ternak, hasil pertanian, perkebunan dan rumput-rumput hasil budidaya yang dapat dijual kepada peternak lain sebagai sumber pendapatan (liquid income).

\section{KESIMPULAN DAN SARAN}

\section{Kesimpulan}

Hasil sintesis pemanfaatan lahan kebun oleh masyarakat Arfak masih terbatas pada segi pemanfaatan ruang dan sumberdaya lahan. Masyarakat Arfak sudah menggunakan praktek agroforestri kompleks dan sederhana.

Terdapat lima pola aliran energi dalam sistem kebun yang belum dimanfaatkan secara efektif dan efisien. Terdapat juga lima kondisi prospek dan konstrain yang harus dilakukan untuk pembangunan berkelanjutan sistem pertanian di Pegunungan Arfak. Dinamika pemanfaatan bio-fertilizer pada outputinput juga masih rendah.

\section{Saran}

Perlu dilakukan adaptasi dan revitalisasi sumberdaya lahan, teknik budidaya pada lahan kebun yang lebih baik lagi. 


\section{DAFTAR PUSTAKA}

Alberto, C., E. Girotto, C. Rogerio, G. Trentin, R. Costa, B. Vieira, and G. Brunetto. 2010. Agrculture, Ecosystems and Environment Nutrient Transfer by Runoff under No Tillage in a Soil Treated with Successive Applications of Pig Slurry. Agriculture, Ecosystems and Environment. 139 (4): 689-699. https://doi.org/10.1016/j.agee.2010.1 0.016 .

Arifin, H.S., C. Wulandari, Q. Pramukanto, dan R.L. Kaswanto. 2009. Analisis Lanskap Agroforestry. $1^{\text {st }}$ ed. IPB Press. Bogor.

Bunch, R. 1991. Dua Tongkol Jagung; Pedoman Pengembangan Pertanian Berpangkal pada Rakyat. $1^{\text {st }}$ ed. Yayasan Obor Indonesia. Jakarta.

Chambers, R., A. Pacey, and L.A Thrupp. 1989. Farmer First. Intermediate Technology Publication. London.

Guntoro, S. 2008. Membuat Pakan Ternak dari Limbah Perkebunan. $1^{\text {st }}$ ed. Agromdia Pustaka. Jakarta.

Hafsah, M.J. 2009. Membangun Pertanian: Sejahtera, Demokratis dan Berkeadilan. $1^{\text {st }}$ ed. Jafar Inspiration. Jakarta.

Hasibuan, M.S.P. 2010. Manajemen Sumberdaya Manusia. $16^{\text {th }}$ ed. Jakrta: Remaja Rosdakarya Offset. Bandung.

Hendrik, J., S. Schrader, H. Marten, and G. Rahmann. 2016. Occasional Reduced Tillage in Organis Farming Can Promote Earthworm Performance and Resource Efficiency. 103: 22-30.
Herudin. 2017. KPK Dalami Keterangan Basuki Soal Mafia Impor Daging di Bulog.

https://www.tribunnews.com/Nasion al/2017/01/30/KpK-DalamiKeterangan-Basuki.

Himawan, A. 2017. Ada Indikasi Mafia Impor Daging dalam UU Peternakan. https://www.suara.com/bisnis/2017/ 01/30/085023/ada-indikasi-mafiaimpor-daging-dalam-uu-peternakan.

Hulupi, R., D. Nugroho, and Yusianto. 2018. Performance of Some Arabica Coffee Local Varieties from Gayo Highland. Pelita Perkebunan. a Coffee and Cocoa Research Journal. 29 (2): 69-81. Doi.org/10.22302.

Iskandar, J. 1992. Ekologi Perdagangan di Indonesia; Studi Kasus Dari Daerah BaduyBAnten Selatan, Jawa Barat. $1^{\text {st }}$ ed. Djambatan. Jakarta.

Mahendra, F. 2009. Sistem Agroforestri dan Aplikasinya. $1^{\text {st }}$ ed. Graha Ilmu. Yogyakarta.

Moleong, L.J. 1991. Metode Penelitian Kualitatif. $3^{\text {rd }}$ ed. Bandung: Remaja Rosdakarya Offset. Bandung.

Mulyadi. 2012. Budaya Pertanian Papua; Perubahan Sosial dan Strategi Pemberdayaan Masyarakat Arfak. $1^{\text {st }}$ ed. Yogyakarta.

Ninez, V. 1987. Household Gardens: Theorotical and Policy Considerations. Agricultural Systems 23: 167-186. Doi.org/10.1016/0308521X(87)90064-3.

Pareja-sanchez, E., D. Plaza-bonilla, M. Concepcion, J. Lampurlanes, J. Alvaro-fuentes, and C. CanteroMartinez. 2017. Soil \& Tillage 
Research Long-Term No-till as a Means to Maintain Soil Surface Structure in an Agroecosystem Transformed into Irrigation. 174:221-230.

Doi.org/10.1016/j.still.2017.07.012.

suhardiSalem, H.M. C. Valero, M. Angel, G. Maria, and L.L. Silva. 2015. Geoderma Short-Term Effects of Four Tillage Practices on Soil Physical Properties, Soil Water Potential, and Maize Yield. Geoderma 237-238:60-70. Doi.org/10.1016/j.geoderma.2014.08 .014 .

Salim, E. 1988. Pembangunan Berwawasan Lingkungan. $2^{\text {nd }}$ ed. Midas Surya Grafindo. Jakarta.

Soekartawi. 2005. Prinsip Dasar Komunikasi Pertanian. $1^{\text {st }}$ ed. Universitas Indonesia. Jakarta. 2010. Agribisnis. $9^{\text {th }}$ ed. Rajagrafinso Persada. Jakarta.

Suhardi, S.A. Sudjoko, Minarningsi. S. Sabarnurdin, dan A. Widodo. 2002. Hutan an Kebun sebagai Sumber Pangan Nasional. $5^{\text {th }}$ ed. Kanisius. Yogyakarta.

Sukria, H.A. dan R. Krisnan. 2009. Sumber dan Ketersediaan Bahan Baku Pakan di Indonesia. $1^{\text {st }}$ ed. IPB. Bogor.

Suratiyah, K. 2008. Ilmu Usahatani. $2^{\text {nd }}$ ed. Penebar Swadaya. Jakarta.

Syed, N. 2018. The Influence of Conservation Tillage and Conventional Tillage on Soil Bacterial Diversity in Southern Illinois.

Wambrauw, L. A. Ungirwalu, S. Syaranamual, L.Y. onbait, and Y.
Wambrauw. 2015. Studi Masterplan

Pembangunan Pertanian di Pegunungan Arfak. Manokari.

Yin, R.K. 2000. Studi Kasus: Desain dan Metode. Radja Grafindo Persada. Jakarta. 